\title{
A Comparison of Competences for Healthcare Professions in Europe
}

\author{
Antonio Sánchez-Pozo \\ Department of Biochemistry, Faculty of Pharmacy, University of Granada, Campus Cartuja s/n, Granada 18071, \\ Spain; sanchezpster@gmail.com; Tel.: +34-958-243-842
}

Academic Editor: Jeffrey Atkinson

Received: 5 December 2016; Accepted: 16 February 2017; Published: 21 February 2017

\begin{abstract}
In Europe and elsewhere, there is increasing interest in competence-based education (CBE) and training for professional practice in healthcare. This review presents competences for pharmacy practice in Europe and compares them with those for medicine and dentistry. Comparisons amongst competence frameworks were made by matching the European Directive for Professional Qualifications in sectoral professions such as healthcare (EU directive) with the frameworks of competences elaborated by European consortia in pharmacy (PHAR-QA), medicine (MEDINE), and dentistry (ADEE). The results show that the recommendations of the EU directive for all three professions are similar. There is also widespread similarity in the formulation of competences for all healthcare professions. Furthermore, for medicine and pharmacy, the rankings by practitioners of the vast majority of competences are similar. These results lay the foundations for the design of more interdisciplinary educational programs for healthcare professionals, and for the development of team-based care.
\end{abstract}

Keywords: competences; education; pharmacy; healthcare professions

\section{Introduction}

In Europe, and elsewhere in the world, there is an increasing shift from content-based to competence-based education (CBE) and practice. In healthcare sciences, this process started in medicine [1] and is now developing in pharmacy. This shift can bring many advantages. Competences for practice are better understood by the society at large, and thus provide a clearer public statement of the role of the healthcare practitioner. Competences are useful in the mutual recognition of qualifications amongst institutions and government bodies, especially at an international level as amongst European member states. CBE promotes greater comparability and compatibility in educational programs, thus facilitating student and practitioner mobility. The CBE approach also stimulates the development of advanced practice. In European pharmacy, CBE is at present limited; student [2] and practitioner mobility is low [3], and advanced practice, although developing, is still not recognized by the EU [4].

Competence frameworks for pharmacy education have emerged during the last years both at national, European, and worldwide levels. These have been promoted by professional chambers and associations, and academia [5-15]. European frameworks have been proposed for other healthcare sciences such as medicine (MEDINE: Medical education in Europe) [16] and dentistry (ADEE: Association for Dental Education in Europe) [17].

In this paper, we compared the CBE framework for EU pharmacies developed by the PHAR-QA (Quality assurance in European pharmacy education and training) [13] consortium (a follow-up to the PHARMINE (Pharmacy education in Europe) [14] project) with those for medicine (MEDINE [16]) and dentistry (ADEE [17]).

The comparison was carried out in three parts: 
1. The recommendations for the minimum requirements of the EU directive [4].

2. The formulations of the academic proposals for CBE in healthcare sciences.

3. The perception by practitioners of the framework proposals for pharmacy and medicine. (This step has not to our knowledge been undertaken in dentistry).

EU Directives of the European Parliament and of the Council on the recognition of professional qualifications have consolidated a system of mutual recognition. It provides for automatic recognition for a limited number of professions based on harmonized minimum training requirements (sectoral professions), a general system for the recognition of evidence of training and automatic recognition of professional experience. The directives have also established a new system of the free provision of services.

Evaluation of the perception of practitioners is an essential step in building a framework. To do this, practitioners rank the competences proposed according to their own development needs, after reflection on the competences required for their particular professional practice. Faculties and other academic institutions have collaborated in the establishment of a framework of competences based on the scientific advances and new methodologies in education. Examples of this collaboration include the PHARMINE and MEDINE. However, the academic knowledge of the problems have to be tested in the working places. This dual approach —an academic proposal followed by ranking by practitioners-is an integral part of the production of a viable framework.

\section{Results and Discussion}

\subsection{The Recommendations for Minimum Requirements of the European Directive}

The 2013 EU directive on the recognition of professional qualifications [4], an amendment of the 2005 EU directive [18], deals mainly with structural management issues, such as length of degree course and the attributes of training, rather than competences. It does, however, set out a series of minimum requirements for the healthcare sciences (Table 1).

Table 1. The minimum requirements for healthcare professions as given in the 2005 EU directive [4].

\begin{tabular}{lccc}
\hline Requirement & Pharmacy & Medicine & Dentistry \\
\hline The sciences upon which practice is based & $X$ & $X$ & $X$ \\
The scientific methods including the principles of measurement & $X$ & $X$ & $X$ \\
Evaluation of scientific data & $X$ & $X$ & $X$ \\
Structure, function and behavior of healthy and sick persons & $X$ & $X$ & $X$ \\
Traineeship in a community or hospital setting & $X$ & $X$ & $X$ \\
Clinical disciplines and practices & & $X$ & $X$ \\
\hline
\end{tabular}

As shown in Table 1, the requirements of the EU directive for the sectoral professions of pharmacy, medicine (general practice), and dentistry have many things in common. Education and training for all three types of practitioner require basic science, human physiopathology, and clinical experience.

Only the requirements for medicine and dentistry, however, emphasize clinical disciplines in which the professional is in direct contact with healthy or sick individuals. However, there has been an evolution in pharmacy from the EU directive in its 2005 version [18] to its 2013 version [4] (Table 2), with the installation of a more "clinical" role for pharmacists as far as patient centered care and public health is concerned. Others professions such as nurses and midwives have also had changes in their requirements, whereas medicine and dentistry remain unchanged. 
Table 2. Description of the roles of pharmacist given in the 2005 and 2013 EU directives. Differences in EU directives concerning patient care and public health issues are given in bold.

\begin{tabular}{|c|c|}
\hline EU Directive 2005 [18] & EU Directive 2013 [4] \\
\hline $\begin{array}{l}\text { Preparation of the pharmaceutical form of medicinal products; } \\
\text { manufacture and testing of medicinal products; testing of } \\
\text { medicinal products in a laboratory for the testing of medicinal } \\
\text { products; storage, preservation and distribution of medicinal } \\
\text { products at the wholesale stage }\end{array}$ & Same as 2005 \\
\hline $\begin{array}{l}\text { Preparation, testing, storage and supply of medicinal products } \\
\text { in pharmacies open to the public }\end{array}$ & $\begin{array}{l}\text { Ordering, manufacture, testing, storage and } \\
\text { dispensing of safe, high quality medicinal } \\
\text { products in public pharmacies }\end{array}$ \\
\hline $\begin{array}{l}\text { Preparation, testing, storage and dispensing of medicinal } \\
\text { products in hospitals }\end{array}$ & Same as 2005 \\
\hline \multirow[t]{3}{*}{ Provision of information and advice on medicinal products } & $\begin{array}{l}\text { Medication management and provision of } \\
\text { information and advice about medicinal } \\
\text { products and general health information }\end{array}$ \\
\hline & $\begin{array}{l}\text { Provision of advice and support to patients in } \\
\text { connection with the use of non-prescription } \\
\text { medicines and self-medication }\end{array}$ \\
\hline & $\begin{array}{l}\text { Contributions to public health and } \\
\text { information campaigns }\end{array}$ \\
\hline
\end{tabular}

It should be noted that the elements given in Tables 1 and 2 are not competences. They describe knowledge or activities. For instance, the requirement "the sciences upon which practice is based" corresponds to the levels ("knows" and "knows how") of Miller's triangle [19]; or the "Provision of information and advice on medicinal products" corresponds to the levels ("shows how" and "does"). However, the EU directive still lacks detail on "competences for practice" and this is one of the reasons why the PHAR-QA, MEDINE, and ADEE academic consortia produced their detailed frameworks for pharmacy, medicine, and dentistry, respectively.

\subsection{The Formulations of the Academic Proposals for CBE in Healthcare Sciences}

A comparison was made of the competence frameworks proposed by academia for pharmacy (PHAR-QA), medicine (MEDINE), and dentistry (ADEE). The major competences were divided into domains as shown in Table 3. We grouped the competences in clusters of related competences: first in groups of very close competences that we called major competences, and then in domains of related major competences. For example, the major competence "professional attributes" includes competences such as probity, honesty, commitment to maintaining good practice, concern for quality, critical and self-critical abilities, reflective practice, and empathy, and the domain "professionalism" includes professional attributes, professional work, and ability to apply ethical and legal principles. This grouping facilitates comparisons, as the individual definitions of competences by the three consortia concerned are not always identical, even though they are talking about the same concept.

The following domains are common to all three professions: professionalism, interpersonal competences, communication and social skills, knowledge base, information and information literacy, clinical information gathering, diagnosis and treatment planning, therapy, establishing and maintaining health, and prevention and health.

The major competences included in the domains of Table 3 account for more than $95 \%$ of the major competences described in the frameworks. They can thus be considered as representative of the frameworks proposed. 
Table 3. Domains and major competences in frameworks of competences for the pharmacist (PHAR-QA), general medical practitioner (MEDINE) and dentist (ADEE).

\begin{tabular}{|c|c|c|c|}
\hline Domain & \multicolumn{3}{|c|}{ Major Competences } \\
\hline \multirow[b]{2}{*}{ 1. Professionalism } & $\begin{array}{l}\text { Personal competences: } \\
\text { values. }\end{array}$ & Professional attributes & $\begin{array}{l}\text { Professional attitude and } \\
\text { behavior }\end{array}$ \\
\hline & $\begin{array}{l}\text { Personal competences: } \\
\text { learning and knowledge. }\end{array}$ & Professional working & \\
\hline $\begin{array}{l}\text { 2. Interpersonal, } \\
\text { communication and } \\
\text { social skills }\end{array}$ & $\begin{array}{l}\text { Personal competences: } \\
\text { communication and } \\
\text { organizational skills. }\end{array}$ & $\begin{array}{l}\text { Communicate effectively in a } \\
\text { medical context }\end{array}$ & Communication \\
\hline $\begin{array}{l}\text { 3. Knowledge base, } \\
\text { information and } \\
\text { information literacy }\end{array}$ & $\begin{array}{l}\text { Personal competences: } \\
\text { learning and knowledge. }\end{array}$ & $\begin{array}{l}\text { Apply the principles, skills and } \\
\text { knowledge of evidence-based } \\
\text { medicine }\end{array}$ & $\begin{array}{l}\text { Application of basic } \\
\text { biological, medical, technical } \\
\text { and clinical sciences }\end{array}$ \\
\hline \multirow[t]{2}{*}{$\begin{array}{l}\text { 4. Clinical information } \\
\text { gathering }\end{array}$} & $\begin{array}{l}\text { Patient care competences: } \\
\text { patient consultation and } \\
\text { assessment. }\end{array}$ & $\begin{array}{l}\text { Carry out a consultation with } \\
\text { a patient }\end{array}$ & $\begin{array}{l}\text { Obtaining and recording a } \\
\text { complete history of the } \\
\text { patient's medical, oral and } \\
\text { dental state }\end{array}$ \\
\hline & & $\begin{array}{l}\text { Assess psychological and social } \\
\text { aspects of a patient's illness' }\end{array}$ & \\
\hline \multirow{2}{*}{$\begin{array}{l}\text { 5. Diagnosis and } \\
\text { Treatment planning }\end{array}$} & $\begin{array}{l}\text { Patient care competences: } \\
\text { need for drug treatment. }\end{array}$ & $\begin{array}{l}\text { Assess clinical presentations, } \\
\text { order investigations, make } \\
\text { differential diagnoses and } \\
\text { negotiate a management plan }\end{array}$ & $\begin{array}{l}\text { Decision-making, clinical } \\
\text { reasoning and judgment }\end{array}$ \\
\hline & $\begin{array}{l}\text { Patient care competences: } \\
\text { provision of information } \\
\text { and service. }\end{array}$ & & \\
\hline \multirow{2}{*}{$\begin{array}{l}\text { 6. Therapy, } \\
\text { establishing and } \\
\text { maintaining health }\end{array}$} & $\begin{array}{l}\text { Patient care competences: } \\
\text { monitoring of drug therapy. }\end{array}$ & Carry out practical procedures & $\begin{array}{l}\text { Establishing and } \\
\text { maintaining oral health }\end{array}$ \\
\hline & & Prescribe drugs & \\
\hline $\begin{array}{l}\text { 7. Prevention and } \\
\text { health promotion }\end{array}$ & $\begin{array}{l}\text { Patient care competences: } \\
\text { patient education. }\end{array}$ & $\begin{array}{l}\text { Promote health, engage with } \\
\text { population health issues and } \\
\text { work effectively in a health } \\
\text { care system }\end{array}$ & $\begin{array}{l}\text { Improving oral health of } \\
\text { individuals, families and } \\
\text { groups in the community }\end{array}$ \\
\hline
\end{tabular}

For each domain, peer major competences appear on the same line, whereas non-equivalent major competences appear on different lines (Table 3). There are gaps in the table (perhaps) representing major competences that (one or more) professions consider implicit.

The first three domains relate to personal competences and are very similar in all healthcare professions. A specific attitude and behavior to patients, together with an ethical commitment, are common aspects of these healthcare professions. Communication and social skills are clearly needed for the information and education of patients. As in many other professions, the use of information technology and the ability to solve problems is a common denominator.

The last four domains (4-7) comprise the specific competences related to patient care. Patient care requires (1) clinical judgment based on competences for gathering information included in the domain "Clinical information gathering"; (2) assessment and treatment planning, included in 
the domain "Diagnosis and Treatment planning"; and (3) monitoring the results, included in the domain "Therapy, establishing and maintaining health." These latter domains are present in all three healthcare professions. We suggest that the decisions about the need for a drug, the selection, dosage, the adverse effects, etc., typically performed by the pharmacist, follow the same principles as other clinical disciplines and thus require the same competences. This is reflected in the increasing role of pharmacists in patient care as recognized by the EU (see above).

\subsection{The Perception by the Practitioners of the Framework Proposals for Pharmacy and Medicine}

In the PHAR-QA [14] and MEDINE [16] projects the competences were ranked by practitioners in each profession.

Figure 1 shows that all competences were considered "necessary" (rank $>2 / 4$ ), although with a considerable degree of variability. Globally, ranking scores for pharmacists and general practitioners were similar, although there were some differences. Knowledge of a second language and research skills were ranked higher by pharmacists; competences such as the ability to work autonomously and to recognize limits were ranked higher by general practitioners.

All patient care competences were considered "necessary" (rank >2/4) (Figure 2). The spread for patient care competences (2.9-3.8) was higher than for personal competences (2-3.8), suggesting that all practitioners rank patient care competences as more important. Rankings were similar for pharmacy and medicine with the global rank being lower for pharmacy than for medicine (delta $=-0.5)$.

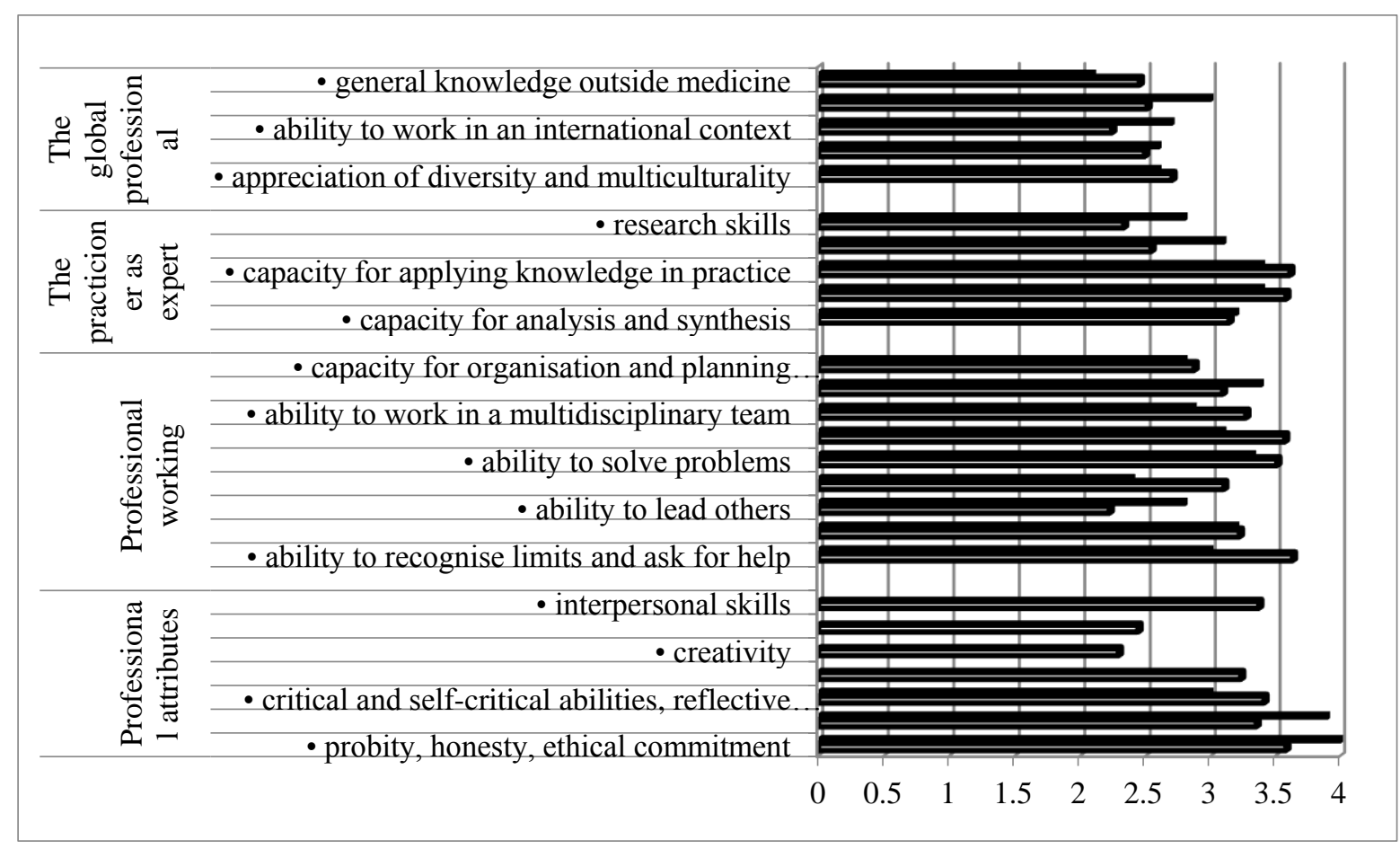

Figure 1. Ranking of personal competences by pharmacy (full columns) and medicine (open columns) practitioners. Ranking was on a 4-point scale ( $1=$ least and $4=$ most important). Pharmacy data are from PHAR-QA [19-22], and for medicine MEDINE [16]. 
'Promote health, engage with population health.

'Ability to apply scientific principles, method.

'Use information and information technology.

'Apply the principles, skills and knowledge of.

'Assess psychological and social aspects of a.'

'Apply ethical and legal principles in practice'

'Communicate effectively // Medicines.

'Carry out practical procedures' // Drug Specific.

'Prescribe drugs'// Need for the drug +.

'Provide immediate care of medical.

'Assess clinical presentations, order.

'Carry out a consultation with a patient'

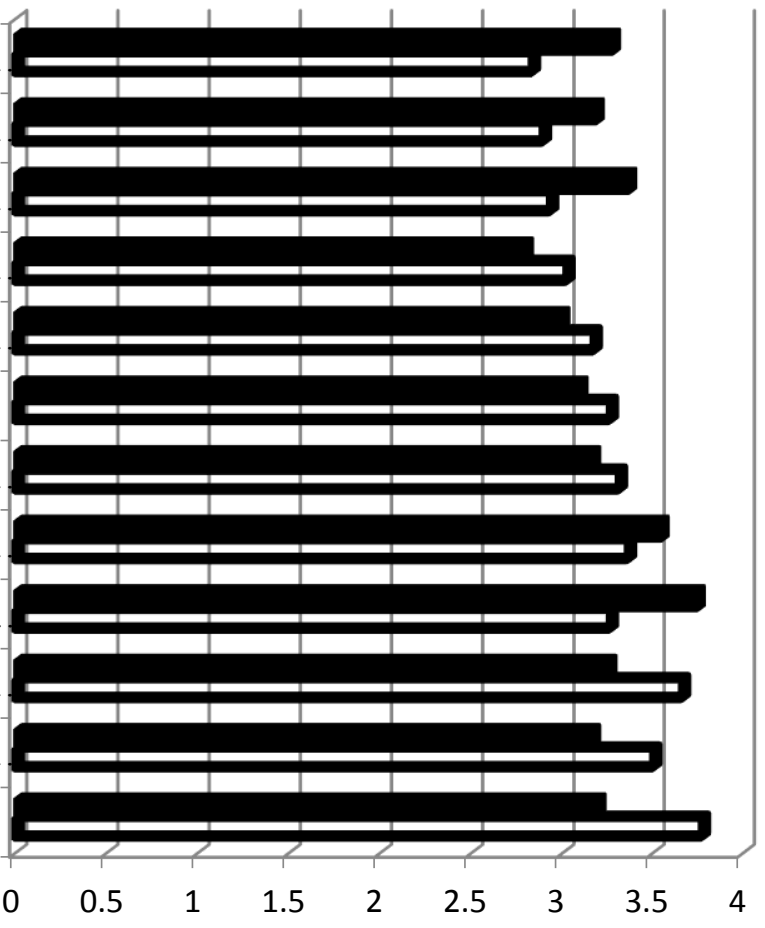

Figure 2. Ranking of patient care competences by pharmacy (full columns) and medicine (open columns) practitioners. Ranking was on a 4-point scale ( $1=$ least and $4=$ most important). Pharmacy data are from PHAR-QA [19-22], and for medicine MEDINE [16].

\section{Conclusions}

The results show that there is much similarity in competences for practice amongst all healthcare professions. This is seen in the recommendations for practice in the EU directive. It is also seen in the formulation of the competences by the different EU academic consortia that have proposed competence frameworks for pharmacy (PHAR-QA, medicine (MEDINE) and dentistry (ADEE)). Finally, it is seen in the perception of pharmaceutical and medical practitioners through their relative ranking of the proposals for competences.

The identification of a large number of competences that are similar in healthcare professions opens up the possibilities of a new design in educational programs with the installation of CBE, of more interaction in the different healthcare disciplines regarding education and practice, and, globally, of programs that are more adequate to an era of team-based healthcare.

Acknowledgments: I wish to thank J. Atkinson for his continuous help and support and for the revision of the manuscript. This work was supported by the Lifelong Learning program of the European Union: 527194-LLP-1-2012-1-BE-ERASMUS-EMCR.

Conflicts of Interest: The author declares no conflict of interest.

\section{References}

1. Frank, J.R.; Snell, L.S.; Cate, T.O.; Holmboe, E.S.; Carraccio, C.; Swing, S.R.; Harris, P.; Glasgow, N.J.; Campbell, C.; Dath, D.; et al. Competency-based medical education: Theory to practice. Med. Teach. 2010, 32, 638-645. [CrossRef] [PubMed]

2. Data on Intra-EU Student Mobility: Strengths and Diversity of European Student Mobility-Agence Erasmus. Available online: https://www.agence-erasmus.fr/docs/2115_soleoscope-10-en.pdf (accessed on 13 January 2017). 
3. Wismar, M.; Maier, C.B.; Glinos, I.A.; Dussault, G.; Figueras, J. (Eds.) Health Professional Mobility and Health Systems: Evidence from 17 European Countries; Observatory Studies Series 23; WHO Regional Office for Europe on Behalf of the European Observatory on Health Systems and Policies: Copenhagen, Denmark, 2011. Available online: http:/ /www.healthpolicyjrnl.com/article/S0168-8510(15)00214-6/fulltext\#bibl0005 (accessed on 13 January 2017).

4. Directive 2013/55/EU of the European Parliament and of the Council of 20 November 2013 Amending Directive 2005/36/EC on the Recognition of Professional Qualifications and Regulation (EU) No 1024/2012 on Administrative Cooperation through the Internal Market Information System ('the IMI Regulation'). Available online: http:/ / eur-lex.europa.eu/legal-content/EN/ALL/?uri=celex\%3A32013L0055 (accessed on 13 January 2017).

5. General Level Framework. A Framework for Pharmacists Development in General Pharmacy Practice. Available online: http://www.codeg.org/fileadmin/codeg/pdf/glf/GLF_October_2007_Edition.pdf (accessed on 13 January 2017).

6. Core Competency Framework for Pharmacists. The Pharmaceutical Society of Ireland. Available online: http: //www.thepsi.ie/gns/pharmacy-practice/core-competency-framework.aspx (accessed on 13 January 2017).

7. Competencias del Farmacéutico Para Desarrollar Los Servicios Farmacéuticos (SF) Basados en Atención Primaria de Salud (APS) y las Buenas Prácticas en Farmacia (BPF). Available online: http:/ / forofarmaceuticodelasamericas.org/wp-content/uploads/2015/04/Competencias-del-farmacéuticopara-desarrollar-los-SF-basados-en-APS-y-BPF.pdf (accessed on 13 January 2017).

8. The American College of Clinical Pharmacy (ACCP). White Paper Clinical Pharmacist Competencies: The American College of Clinical Pharmacy. Pharmacotherapy 2008, 28, 806-815.

9. Medina, M.S.; Plaza, C.M.; Stowe, C.D.; Robinson, E.T.; DeLander, G.; Beck, D.E.; Melchert, R.B.; Supernaw, R.B.; Roche, V.F.; Gleason, B.L.; et al. Center for the Advancement of Pharmacy Education 2013 Educational Outcomes. Am. J. Pharm. Educ. 2013, 77, 162. [CrossRef] [PubMed]

10. Competency Framework for the Pharmacy Profession. Pharmacy Council of New Zealand, 2009. Available online: http://www.pharmacycouncil.org.nz/cms_show_download.php?id=201 (accessed on 13 January 2017).

11. NAPRA. Professional Competencies for Canadian Pharmacists at Entry to Practice. 2007. Available online: http://napra.ca/content_files/files/comp_for_cdn_pharmacists_at_entrytopractice_march2014_b.pdf (accessed on 13 January 2017).

12. National Competency Standards Framework for Pharmacists in Australia. Pharmaceutical Society of Australia, 2010. Available online: https://www.psa.org.au/downloads/standards/competency-standardscomplete.pdf (accessed on 13 January 2017).

13. PHAR-QA (Quality Assurance in European Pharmacy Education and Training). 2016. Available online: http:/ / www.phar-qa.eu/ (accessed on 13 January 2017).

14. The PHARMINE (Pharmacy Education in Europe) Consortium. Work Programme 3: Final Report. Identifying and Defining Competences for Pharmacists. Available online: http:/ /www.pharmine.org/ wp-content/uploads/2014/05/PHARMINE-WP3-Final-ReportDEF_LO.pdf (accessed on 13 January 2017).

15. A Global Competency Framework. FIP Pharmacy Education Taskforce, 2012. Available online: https://www.fip.org/files/fip/PharmacyEducation/GbCF_v1.pdf (accessed on 13 January 2017).

16. Learning Outcomes/Competences for Undergraduate Medical Education in Europe (MEDINE) the Tuning Project (Medicine). Available online: http:/ / tuningacademy.org/medine-medicine/?lang=en (accessed on 13 January 2017).

17. Cowpe, J.; Plasschaert, A.; Harzer, W.; Vinkka-Puhakka, H.; Walmsley, A.D. Profile and Competences for the Graduating European Dentist-Update 2009. Eur. J. Dent. Educ. 2010, 14, 193-202. [CrossRef] [PubMed]

18. Directive 2005/36/EC of the European Parliament and of the Council of 7 September 2005 on the Recognition of Professional Qualifications. Available online: http:/ / eur-lex.europa.eu/legal-content/EN/TXT/?uri= celex:32005L0036 (accessed on 15 February 2017).

19. Miller, G.E. The assessment of clinical skills/competences/performance. Acad. Med. 1990, 65, 63-67. [CrossRef]

20. Atkinson, J.; de Paepe, K.; Sánchez Pozo, A.; Rekkas, D.; Volmer, D.; Hirvonen, J.; Bozic, B.; Skowron, A.; Mircioiu, C.; Marcincal, A.; et al. How do European pharmacy students rank competences for practice? Pharmacy 2016, 4, 8. [CrossRef] 
21. Atkinson, J.; de Paepe, K.; Sánchez Pozo, A.; Rekkas, D.; Volmer, D.; Hirvonen, J.; Bozic, B.; Skowron, A.; Mircioiu, C.; Marcincal, A.; et al. What is a pharmacist: Opinions of pharmacy department academics and community pharmacists on competences required for pharmacy practice. Pharmacy 2016, 4, 12. [CrossRef]

22. Atkinson, J.; Sánchez Pozo, A.; Rekkas, D.; Volmer, D.; Hirvonen, J.; Bozic, B.; Skowron, A.; Mircioiu, C.; Sandulovici, R.; Marcincal, A.; et al. Hospital and Community Pharmacists' Perceptions of Which Competences Are Important for Their Practice. Pharmacy 2016, 4, 21. [CrossRef]

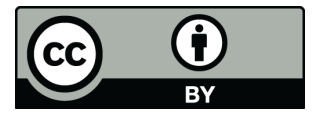

(C) 2017 by the author. Licensee MDPI, Basel, Switzerland. This article is an open access article distributed under the terms and conditions of the Creative Commons Attribution (CC BY) license (http:/ / creativecommons.org/licenses/by/4.0/). 